\title{
Perbandingan aspek ekologi dan karakteristik bulu babi Tripneustes gratilla pada lokasi berbeda
}

\section{Comparisson of ecological aspect and characteristics of sea urchin Tripneustes gratilla at different locations}

\author{
Tasruddin* dan Aonurafiq \\ Fakultas Perikanan, Universitas Muhammadiyah Luwuk \\ Jalan Kh. Ahmad Dahlan no. 79, Luwuk, Sulawesi Tengah 94711 \\ *Surel: dftas@yahoo.com
}

\begin{abstract}
Increasing of population growth leads to the settlement enlargement and constriction spatial of city residence, therefore a coastal reclamation becomes a choice. The reclamation affecting the population and the habitat of sea urchin Tripneustes gratilla by disturbing mutual relationship among organisms. The change of ecological haracteristics could be decreasing sea urchin resources. The T. gratilla culture in Indonesia has not been conducted commercially. Research about $T$. gratilla is limited because lacking of seed, eventhough an artificial spawning technique has been mastered. This research aimed to compare the characteristics of ecological aspect, food source, diameter, body weight, gonad weight, gonad index, specific growth rate (SGR), and survival rate of $T$. gratilla at the different sampling locations in Pelabuhan Tanjung, Tanjung Tuis, Kilongan permai, Biak, and Bolii. The advantage of the research expected to be an effective and efficient solutions in the advance of aquaculture by prioritizing a continuing environment conservation aspect. Experiment and survei method with randomized sampling location applied in five different locations. The results showed that the best sea urchin was in Tanjung Pelabuhan in June with diameter $(55,60 \pm 1,96 \mathrm{~mm})$, total weight $(83,56 \pm 7,84 \mathrm{~g})$, gonad weight $(8,39 \pm 2,99 \mathrm{~g})$ and gonad index $(10,07 \pm 3,60 \%)$. In contrary, the lower quality of sea urchin was in May in Bolii with diameter $(62,20 \pm$ $2,78 \mathrm{~mm})$, total weight $(67,96 \pm 8,94 \mathrm{~g})$, gonad weight $(1,22 \pm 0,58 \mathrm{~g})$, and gonad index $(1,83 \pm 0,86 \%)$. The diameter, total weight, and gonad weight of sea urchin did not equivalent with gonad index. The second phase of this research showed that gonad weight of cultured sea urchin in treatment A was $31.99 \pm 0.38 \mathrm{ag}$, while B was $31.74 \pm 0.61 \mathrm{ab} \mathrm{g}$, and $\mathrm{C}$ was $32.42 \pm 0.56 \mathrm{~b}$ g. The SGR parameter in present study showed no difference among treatments.
\end{abstract}

Keywords: ecological characteristics, gonad index, Tripneustes gratilla

\begin{abstract}
ABSTRAK
Pertambahan penduduk yang semakin meningkat, menyebabkan permukiman dan penataan kota menjadi sempit, reklamasi menjadi salah satu pilihan. Reklamasi pantai berpengaruh pada populasi dan ekosistem bulu babi Tripneustes gratilla sehingga simbiosis mutualisme terganggu. Karakteristik ekologi dapat berdampak pada menurunnya sumberdaya bulu babi. Di Indonesia kegiatan budidaya bulu babi secara komersial belum dilakukan. Penelitian tentang bulu babi untuk budidaya masih sedikit dilakukan karena ketersediaan benih. Penelitian bertujuan membandingkan karakteristik aspek ekologis, sumber pakan, diameter, berat tubuh, berat gonad, indeks gonad, survival growth rate dan tingkat kelangsungan hidup bulu babi diperairan Pelabuhan Tanjung, Tanjung Tuis, Kilongan permai, Biak, dan Bolii. Kegunaan penelitian ini diharapkan menjadi solusi dalam pengembangan akuakultur dengan mengedepankan aspek kelestarian lingkungan yang berkelanjutan. Metode penelitian yang digunakan yaitu survei dan experimen dilakukan secara acak. Hasil survei menunjukkan bahwa pada lokasi Tanjung Pelabuhan, diameter bulu babi terbaik di bulan Juni $(55,60 \pm 1,96 \mathrm{~mm})$, berat utuh $(83,56 \pm 7,84 \mathrm{~g})$, berat gonad $(8,39 \pm 2,99 \mathrm{~g})$, dan indeks gonad $(10,07 \pm 3,60 \%)$. Terendah bulan Mei di lokasi Bolii, diameter $(62,20 \pm$ $2,78 \mathrm{~mm})$, berat utuh $(67,96 \pm 8,94 \mathrm{~g})$, berat gonad $(1,22 \pm 0,58 \mathrm{~g})$, dan indeks gonad $(1,83 \pm 0,86 \%)$. Diameter bulu babi, berat utuh, dan berat gonad tidak berbanding lurus dengan indeks gonad. Eksperimen kedua menunjukkan bahwa berat gonad pada budidaya perlakuan A $(31,99 \pm 0,38 \mathrm{a} \mathrm{g})$, B $(31.74 \pm 0.61 \mathrm{ab} \mathrm{g})$, dan C $(32,42 \pm 0,56 \mathrm{~b} \mathrm{~g})$. Sementara parameter SGR yang didapatkan pada penelitian ini tidak berbeda nyata antarperlakuan.
\end{abstract}




\section{PENDAHULUAN}

Bulu babi Tripneustes gratilla termasuk filum Echinodermata dari kelas Echinoidea yang memiliki nilai komersial penting sehingga banyak dieksploitasi. Bulu babi dipanen oleh manusia untuk diambil gonadnya (roe) sebagai sumber makanan sejak masa mengenal sumber protein bewani (Lawrence, 2007). Gonad bulu babi sebagai produk perikanan telah menjadi komoditi penting di berbagai negara (Keesing \& Hall, 1998). Cili, Amerika Serikat, Jepang, Rusia, Cina dan Kanada merupakan produsen utama bulu babi (FAO, 2012), sementara Jepang merupakan pengimpor dan konsumen gonad bulu babi terbesar yang menyerap lebih dari $80 \%$ produksi bulu babi dunia (Agatsuma et al., 2010).

Ketersediaan bulu babi di berbagai negara terus menurun akibat tangkap lebih, di sisi lain permintaan selalu ada bahkan terus meningkat, kondisi ini telah menciptakan kesempatan bagi kegiatan akuakultur bulu babi (Andrew et al., 2002). Produksi bulu babi, Evechinus chloroticus telah dilakukan diberbagai negara, seperti Selandia Baru (Barker, 2010), Strongylocentrotus droebachiensis di Norwegia (Hagen \& Siikavuopio, 2010), Echinus esculentus, Psammechinus miliaris, dan Paracentrotus lividus di Scotlandia dan Irlandia (Kelly \& Chamberlain, 2010), Anthocidaris crassispina, Strongylocentrotus nudus, dan S. intermedius di Cina (Liu et al., 2010) serta S. droebachiensis, $S$. franciscanus dan S. purpuratus di Kanada (Pearse \& Robinson, 2010).

Kegiatan akuakultur bulu babi $T$. gratilla Linnaeus 1758 di Indonesia secara komersial belum dilakukan. Penelitian tentang bulu babi untuk akuakultur masih sedikit dilakukan, kondisi ini berujung tidak tersedianya benih bagi kegiatan akuakultur. $T$. gratilla merupakan jenis bulu babi tropis ekonomis penting di Indonesia. Terutama pada ekosistem lamun, biota ini tersebar di Kawasan Tengah dan Timur Indonesia seperti Bali, Nusa Tenggara, Sulawesi, dan Maluku. T. gratilla memiliki tingkat pertumbuhan yang cepat, kualitas gonadnya memenuhi selera pasar, berwarna kuning cerah sampai oranye dengan tekstur halus sampai kasar (berbutir) dan berbau khas produk laut (Lawrence \& Agatsuma, 2007).

Bulu babi merupakan salah satu jenis yang mempunyai nilai ekonomis penting, dari sekian banyak sumberdaya hayati yang berasal dari laut. Bulu babi merupakan bahan makanan yang berprotein tinggi. Sumberdaya perikanan, seperti bulu babi tersebut cukup prospektif untuk dikembangkan. Nilai prospetif seperti gonade, dikalangan masyarakat belum memanfaatkan secara optimal, hal ini diakibatkan oleh masih kurangnya informasi dan pengetahuan mengenai manfaat dan kegunaan daripada bulu babi spesies T. gratilla. Pemanfaatan sumberdaya hayati perairan harus diusahakan seoptimal mungkin tanpa mengganggu kelestariannya. Mengingat usaha pengembangan sistem dan metode budidaya bulu babi yang prospektif, maka perlunya langkah-langkah konkrit untuk mengetahui karakteristik dan aspek bilogis dan ekologisnya.

Upaya peningkatan produksi bulu babi memerlukan pengetahuan dan teknik budidaya yang komprehensif, sehingga populasi dan restoking dapat terkendali. Sifat-sifat ekologi, biologi dan kondisi perairan yang layak, merupakan suatu instrument bahwa kegiatan budidaya bulu babi dapat dioptimalkan, salah satu diantaranya jenis pakan dan kebiasaan makan, serta aspek lingkungan. Karakteristik, aspek biologi dan ekologi, serta faktor pakan merupakan indikator dalam pengembangan budidaya bulu babi, sehingga dapat mempercepat pertumbuhan, persentase kelangsungan hidup, dan indeks gonad.

Sifat-sifat ekologi, biologi, dan kondisi perairan yang layak, merupakan suatu instrumen bahwa kegiatan budidaya bulu babi dapat dioptimalkan, salah satu diantaranya jenis pakan dan kebiasaan makan,serta aspek lingkungan. Karakteristik, aspek biologi, dan ekologi, serta faktor pakan merupakan indikator dalam pengembangan budidaya bulu babi, sehingga dapat mempercepat pertumbuhan, persentase kelangsungan hidup dan indeks gonad.

Penelitian ini dilaksanakan dengan dua tahap pada bulan April sampai dengan bulan Juni 2014. Penelitian ini akan dilaksanakan pada dua tahap di lima lokasi yaitu di pesisir perairan pantai Kelurahan Tanjung. Tuis kilometer 8, Kilongan Permai, Biak, Tanjung Kel. Keraton dan pesisir perairan Bolii, Kabupaten Banggai. Tahap kedua pemeliharaan untuk pengembangan akuakultur dilaksanakan di pembesaran ikan kerapu, Kelurahan Tanjung Tuis Kecamatan Luwuk Selatan, Kabupaten Banggai.

\section{BAHAN DAN METODE}

\section{Tahap pertama}

Tahap pertama dengan melakukan survei, 
membandingkan karakteristik habitat, diameter, berat, berat gonad dan indeks gonad bulu babi. Diameter dan berat bulu babi dibandingkan, setiap lokasi, sehingga berat dan diameter menjadi parameter untuk menentukan indeks gonad, sedangkan karakteristik ekologi merupakan parameter warna gonad.

Gonad difiksasi dalam larutan Bouin's fix untuk perlakuan selanjutnya dalam proses pembuatan preparat gonad. Preparat dibuat menggunakan metode parafin blok dengan pewarnaan hematoxylin dan eosin. Pengamatan mikroskopis preparat gonad dilakukan untuk mengetahui jenis kelamin dan tingkat perkembangan gametogenesisnya.

Tahap ini, analisis proksimat gonad, histologi gonad, dan indeks gonad bulu babi dari lima lokasi, kemudian dibandingkan pada masing-masing lokasi tersebut, sehingga dapat menentukan lingkungan dan karakteristik untuk pengembangan pembudidayaan. Perbandingan karakteristik ekologi dan pakan dapat memberikan petunjuk untuk kegiatan budidaya.

\section{Tahap kedua}

Tahap kedua dengan eksperimen, pemeliharaan organisme uji untuk pengembangan budidaya, sehingga dapat memanfaatkan pakan buatan, yang dipelihara di wadah terkontrol. Eksperimen ini dilakukan selama empat puluh lima hari sehingga dapat membandingkan indeks gonad alam dan gonad hasil budidaya. Namun terjadi fenomena alam, sehingga eksperimen tersebut hanya terlaksana selama dua puluh satu hari.

\section{Wadah penelitian}

Wadah eksperimen tahap kedua yang digunakan adalah ember plastik, dengan ukuran: tinggi $\times$ diameter, $\left(52 \times 37 \mathrm{~cm}^{2}\right)$, dengan volume wadah $=35 \mathrm{~L} /$ wadah.

\section{Organisme uji}

Organisme uji yang digunakan pada penelitian ini adalah $T$. gratilla dengan berat awal untuk tahap pertama yaitu: 34-100 g/ekor dan diameter 43-66 mm. Pada eksperimen tahap kedua, pengembangan akuakultur berat organisme uji berkisar antara $34 \pm 0,5 \mathrm{~g}$ dengan diameter $38 \pm 0,5 \mathrm{~mm}$. Sebelum dilakukan penebaran pada masing-masing wadah, terlebih dahulu dilakukan aklimatisasi, tanpa diberi pakan selama empat hari. Hal ini dimaksudkan agar gonad dan pakan dikeluarkan, sehingga dapat menentukan penggunaan pakan dan perkembangan gonad.
Bulu babi yang digunakan dalam tahap kedua yaitu dari lokasi perairan Kilongan Permai, Biak, Bolii, Tanjung Pelabuhan Luwuk dan Tanjung Tuis. Morfologi gonad organisme uji pada (Gambar 1) berikut:

\section{Parameter yang diamati}

Parameter diamati yaitu laju pertumbuhan spesifik harian, sintasan, diameter, berat tubuh, berat gonad, indeks gonad, proksimat gonad, dan kualitas air.

\section{Laju pertumbuhan spesifik harian (SGR)}

Laju pertumbuhan spesifik harian organisme uji selama penelitian dihitung menggunakan rumus Zonneveld (1991):

$$
\mathrm{g}=[(\mathrm{Ln} \mathrm{Wt}-\mathrm{Ln} \mathrm{Wo}) / \mathrm{t}] \times 100
$$

\section{Keterangan:}

$\mathrm{Wt}=$ berat bulu babi pada waktu $\mathrm{t}(\mathrm{g}$

Wo $=$ berat awal bulu babi $(\mathrm{g})$

$\mathrm{g} \quad=$ laju pertumbuhan harian

$\mathrm{t}=$ waktu pengamatan

$\mathrm{Ln}=$ logaritma natural

\section{Kelangsungan hidup}

Penimbangan bobot biomassa organisme uji dilakukan setiap tujuh hari dengan menimbang semua organisme yang ada pada setiap wadah. Tingkat kelangsungan hidup bulu babi dihitung dengan menggunakan rumus Effendie (1978):

$$
\mathrm{SR}=\mathrm{Nt} / \mathrm{No} \times 100
$$

Keterangan:

$\mathrm{SR}=$ tingkat kelangsungan hidup $(\%)$

$\mathrm{Nt}=$ populasi pada waktu $\mathrm{t}$ (ekor)

No $=$ populasi pada awal penelitian (ekor)

\section{Indeks kematangan gonad}

Indeks kematangan gonad dihitung berdasarkan Jangoux dan Lawrence (1982), yaitu:

$$
\mathrm{IG}=\mathrm{RG} / \mathrm{BTb} \times 100
$$

Keterangan:

$$
\begin{aligned}
& \mathrm{IG}=\text { indeks gonad } \\
& \mathrm{RG}=\text { rasio massa gonad } \\
& \mathrm{BTb}=\text { berat total bulu babi }
\end{aligned}
$$

\section{Kualitas air}

Untuk menunjang hasil penelitian dilakukan pengukuran beberapa parameter kualitas air yang 
meliputi salinitas, suhu, dan $\mathrm{pH}$. Pengukuran beberapa parameter kualitas air dilakukan setiap minggu, yaitu pada pagi hari pukul 07.00 dan sore hari pukul 17.00 WITA.

\section{HASIL DAN PEMBAHASAN}

\section{Laju pertumbuhan spesifik harian}

Berdasarkan hasil pengukuran laju pertumbuhan spesifik harian, menunjukkan bahwa diantara perlakuan tidak berbeda nyata dimana perlakuan A $(0,19 \pm 0,13 \%)$, B $(0,17 \pm 0,14 \%)$ dan C $(0,18 \pm 0,15 \%)$. Hal ini diduga bahwa setelah minggu ketiga terjadi fenomena alam yang menyebabkan kualitas air mulai menurun dengan tingkat kekeruhan yang cukup tinggi disertai curah hujan, sehingga organisme uji tak dapat mentolerir lingkungan. Kondisi ini tidak dapat dipertahankan sampai akhir penelitian, karena organisme uji mulai mengalami kematian.

\section{Kelangsungan hidup}

Percobaan kedua menunjukkan bahwa organisme uji mengalami kematian 100\% setelah terjadinya fenomena alam. Hal ini diduga akibat kualitas air dan tingkat pengendapan lumpur pada wadah yang cukup tinggi akibat kekeruhan. Kondisi ini disebabkan oleh faktor cuaca, yaitu pada bulan September-Oktober intensitas curah hujan dan kecepatan angin dan gelombang sangat tinggi, sehingga organisme uji tak dapat mentolerir kondisi lingkungan dan pakan yang diberikan tak dapat termanfaatkan, menyebabkan organisme uji mati.

\section{Diameter, berat tubuh, berat gonad, dan} indeks gonad bulu babi

Berdasarkan hasil tahap pertama masingmasing lokasi, menunjukkan bahwa rata-rata diameter, berat tubuh, berat gonad, dan indeks gonad pada periode bulan purnama terbaik adalah lokasi 4, (berat gonad : April $=3,70 \pm 0,73$ g; Mei $=5,12 \pm 2,51$ g dan Juni $=4,72 \pm 0,92$ g), diikuti lokasi lokasi $2(3,42 \pm 1,28 \mathrm{~g} ; 4,60 \pm 0,70 \mathrm{~g}$; $3,87 \pm 1,60 \mathrm{~g})$, lokasi $5(2,66 \pm 0,43 \mathrm{~g} ; 2,62 \pm 0,58 \mathrm{~g}$; $3,52 \pm 1,58 \mathrm{~g})$, lokasi $1(1,97 \pm 0,72 \mathrm{~g} ; 1,63 \pm 0,53$

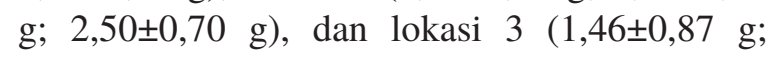
$1,73 \pm 0,88 \mathrm{~g} ; 4,85 \pm 2,26 \mathrm{~g})$. Rerata diameter, berat tubuh, berat gonad dan indeks gonad bulu babi setiap lokasi pada periode bulan purnama (Gambar 2), menunjukkan bahwa diameter dan berat tubuh bulu babi tidak berbanding lurus dengan berat gonad. Hal ini dapat terlihat dari penyebaran bulu babi dari lima lokasi, dimana diameter dan berat tubuh bulu babi yang cukup besar, namun berat gonad lebih kecil, demikian pula indeks gonadnya.

Hal ini diduga bahwa faktor makanan, sumber makanan dan genetis merupakan salah satu indikator yang mempengaruhi diameter, berat tubuh dan berat gonad T. gratilla. Ukuran T. gratilla dapat dipengaruhi oleh beberapa faktor termasuk ketersediaan makanan (James \& Siikavuopio, 2012). Sehubungan dengan itu (Barker, 2010) mengemukakan bahwa cara makan dan macam makanan pada berbagai biota pada umumnya adalah cukup penting, mengingat bahwa makanan dan proses metabolisme merupakan pemindahan energi yang kelak akan menunjang proses pertumbuhan, reproduksi, dan upaya untuk kesinambungan kehidupan biota tersebut. Disamping itu faktor karakteristik ekologi dari masing-masing lokasi juga dapat mempengaruhi rata-rata diameter, berat tubuh, berat gonad dan indeks gonad.

Pada (Gambar 3) menunjukkan bahwa (bulan Juni) indeks gonad terbaik adalah lokasi Tanjung Pelabuhan Luwuk diikuti Tanjung Tuis, Bolii, Kilongan permai dan Biak. Selanjutnya indeks gonad terbaik pada bulan Mei yaitu Biak, diikuti Tanjung Pelabuhan Luwuk dan disusul Tanjung Tuis, Kilongan permai dan terendah pada lokasi

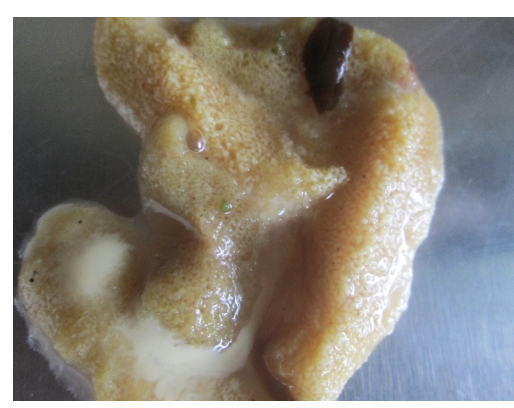

(a)

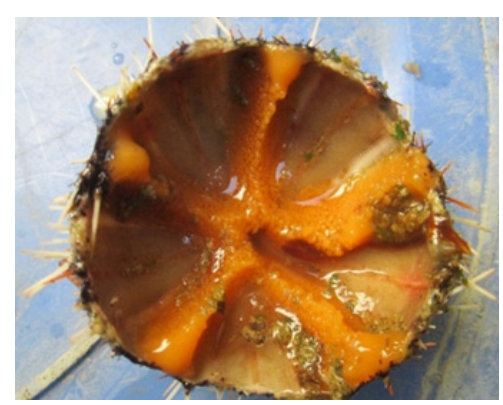

(b)

Gambar 1. Morfologi gonad Tripneustes gratilla 
Bolii. Kemudian untuk bulan April indeks gonad yang terbaik, yaitu Tanjung Pelabuhan Luwuk di ikuti lokasi Biak, Kilongan permai, Tanjung Tuis dan indeks gonad terendah yaitu perairan Bolii.

Faktor-faktor yang menyebabkan terjadinya perbedaan indeks gonad pada setiap lokasi, diduga adalah faktor ketersediaan makanan, karakteristik ekologi dan siklus bulan. Semakin berat gonad maka akan menunjukkan ideks gonad yang lebih baik. Oleh karena itu diameter dan berat tubuh bulu babi tidak menggambarkan signifikansi dari pada indeks gonad. Kondisi dimana berat gonad yang baik dan indeks gonadnya baik juga dipengaruhi oleh siklus bulan, utamanya bulan purnama dan bulan tiga puluh malam dilangit. Hal ini sesuai dengan hasil pengamatan gonad bulu babi Muthiga (2005). Tekstur padat (kompak) terjadi pada gonad fase pemulihan (recoveraly), dan kondisinya menurun (melunak) sepanjang proses pematangan gamet.

Rerata diameter, berat tubuh, berat gonad dan indeks gonad bulu babi di lima lokasi pada periode tiga puluh malam bulan di langit (bulan penuh), selang April sampai Juni pada lima lokasi, (Gambar 4) dan (Gambar 5), menunjukkan bahwa berat gonad yang diambil saat periode 30 lokasi Tanjung Pelabuhan luwuk memperlihatkan rata-rata berat gonad terbaik, diikuti oleh lokasi perairan Biak, perairan Tanjung Tuis, perairan Bolii dan perairan Kilongan Permai.

Faktor yang menunjukkan perbedaan berat gonad pada lima lokasi diperiode tiga puluh malam bulan di langit adalah faktor ketersedian pakan, karakteristik ekologi dan siklus bulan. Ketersediaan pakan ditentukan oleh tingkat kesuburan perairan, dimana kondisi lingkungan berperan sebagai supplier sumber-sumber organik yang dapat mendorong dan meningkatkan kualitas pakan diperairan. Konfigurasi indeks gonad pada periode bulan purnama (bulan baru) dan tiga puluh malam bulan dilangit (bulan penuh), pada waktu pengambilan sampel di lima lokasi, ditunjukkan pada Gambar 6.

Gambar 6 menunjukkan bahwa antara periode bulan purnama dan tiga puluh malam bulan di langit (bulan penuh) indeks gonad dimasingmasing lokasi berbeda dalam kurun waktu pengambilan sampel yaitu April, Mei, dan Juli. Perbedaan indeks gonad dimasing-masing lokasi berbeda diduga ketersedian pakan, karakteristik ekologi dan siklus bulan. Perbedaan indeks gonad di masing-masing lokasi berbeda diduga disebabkan oleh ketersedian pakan, karakteristik ekologi dan siklus bulan.
Siklus bulan atau fotoperiode dapat memberikan perbedaan tentang indeks gonad dan karakteristik gonad. Intensitas cahaya bulan pada tiga puluh malam bulan dilangit sangat pendek, jika dibandingkan dengan bulan purnama hal ini berpengaruh pada jangkauan pasang surut. Bulu babi bersifat nokturnal dan omnivora lebih cenderung aktivitas cari pakan di malam hari yang panjang gelap lebih lama daripada terang. Indeks gonad di bulan purnama lebih kecil, karena bulu babi tidak menyukai cahaya terang yang relatif panjang. Kondisi inilah yang menyebabkan antara bulan purnama dan bulan gelap terjadi perbedaan indeks gonad dimasing-masing lokasi. Sehubungan dengan itu efek dari temperatur air laut pada pola reproduksi bulu babi dengan indeks gonad dan siklus bulanan dengan suhu air laut rata-rata bulana (Muthiga, 2005). Pembacaan irisan gonad berdasarkan lokasi di periode bulan purnama ditampilkan pada Gambar 7.

Pembacaan gambaran histologi berdasarkan Walker et al. (2007) yang membagi perkembangan siklus reproduktif bulu babi dalam empat fase, yaitu (1) 'inter-gametogenesis dan NP phagocytosis', (2) 'pre-gametogenesis dan NP renewal', (3) 'gametogenesis dan NP utilization', (4) 'end of gametogenesis, NP exhaustion dan spawning' dari T. gratilla. (A) Betina dan (B) jantan.

Berdasarkan analisis histologi pada pembacaan irisan gonad diduga bahwa periode antara bulan purnama (kuartal kedua) dan tiga puluh malam bulan dilangit (kuartal ketiga) menunjukkan bahwa ada korelasi antara indeks gonad dan reproduksi $T$. gratilla terhadap periode kuartal bulan tersebut.

Siklus reproduksi tahunan, beberapa spesies bulu babi telah terbukti menunjukkan ritme bulanan $T$. gratilla di masa kini. Studi menunjukkan ritme reproduksi yang bertepatan erat dengan fase perubahan bulan dengan indeks gonad memuncak setelah akhir kuartal pertama dan menurun menjadi minimal sekitar kuartal ketiga menunjukkan bahwa pemijahan mungkin terjadi saat itu juga. (Muthiga, 2005)

Perkembangan gonad seringkali digunakan sebagai indeks dari kondisi nutrisi bulu babi, tidak hanya dikarenakan ketergantungan pertumbuhan gonad terhadap kualitas diet, tetapi juga dikarenakan bulu babi relatif cukup besar menginvestasikan nutrisi dalam upaya reproduksi, ditandai saat matang gonad bagian dalam cangkang akan dilingkupi pundi-pundi gonad (Purbiantoro, 2013) 


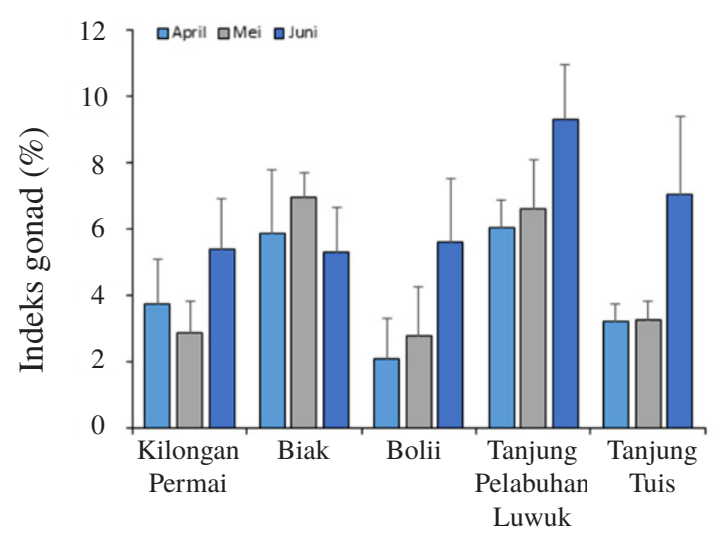

Lokasi pengambilan sampel

Gambar 2. Indeks gonad bulu babi Tripneustes gratilla yang diambil saat periode bulan purnama dari lima lokasi berbeda ( $\mathrm{n}=10$ individu/lokasi/bulan).

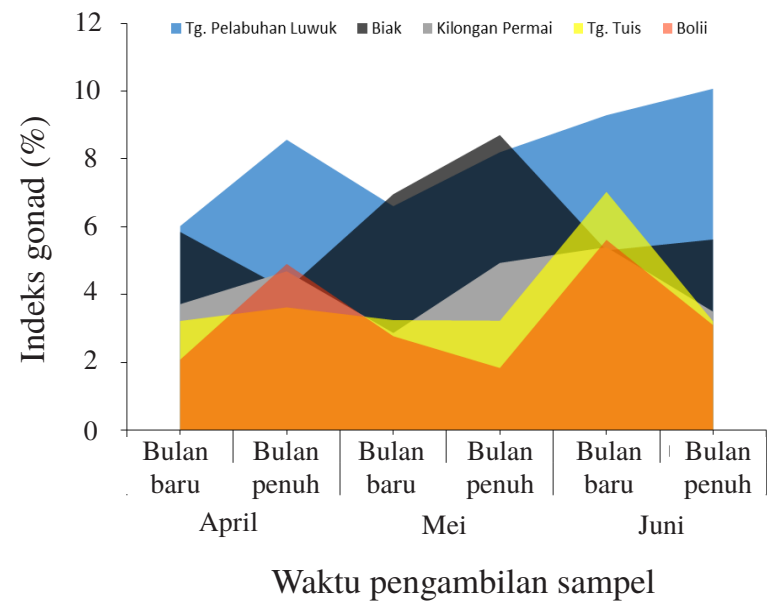

Gambar 6. Indeks gonad bulu babi yang diambil saat periode bulan purnama dan tiga puluh malam bulan dilangit (bulan penuh) dari lima lokasi berbeda $(n=10$ individu/lokasi/bulan).

\section{Proksimat gonad Tripneustes gratilla}

Hasil analisis proksimat lengkap T. gratilla menunjukkan bahwa kadar air (14,58\%), kadar abu $(10,86 \%)$, protein $(47,75 \%)$ Lemak $(12,10 \%)$ dan karbohidrat (serat kasar: 0,35\%, BETN: 14,36\%). Sumber Laboratorium Nutrisi Ikan Departemen Budidaya Perairan Fakultas Perikanan dan Ilmu Kelautan Institut Pertanian Bogor.

\section{Kualitas air}

Parameter kualitas air yang diukur dilima lokasi berkisar antara : Salinitas 32-33 ppt, suhu 31-32 ${ }^{\circ} \mathrm{C}$ dan $\mathrm{pH} 7,3-7,4$. Kisaran kualitas air pada lima lokasi tersebut menunjukkan bahwa kondisi lingkungan perairan masih ideal untuk pertumbuhan dan perkembangbiakan bulu babi tersebut. Kondisi ini menggambarkan bahwa

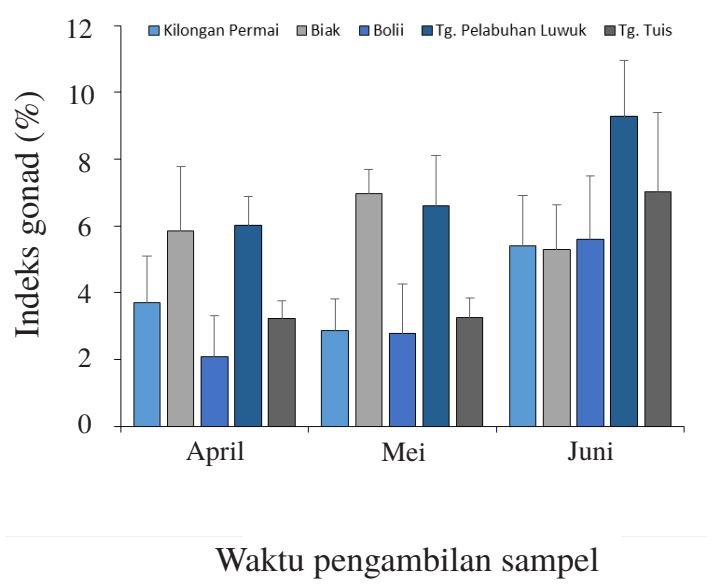

Gambar 3. Indeks gonad Tripneustes gratilla yang diambil saat periode bulan purnama dari lima lokasi berbeda ( $\mathrm{n}=10$ individu/lokasi/bulan).

proses-proses fisiologis berlangsung secara sempurna.

\section{KESIMPULAN}

Laju pertumbuhan spesifik growth rate tidak berbeda ntaya, diameter, berat tubuh, berat gonad dan indeks gonad, ditentukan oleh, faktor pakan, ketersediaan pakan, karakteristik ekologi, period bulan dan lingkungan yang ideal. Karakteristik ekologi dan pakan akan menggambarkan dan memperlihatkan bahwa gonad dan indeks gonad dalam setiap lokasi berbeda. Rendahnya kelangsungan hidup, merupakan indikator untuk perlunya penenelitian lebih lanjut, sehingga dapat mengukur tingkat pertumbuhan, gonad, diameter dan berat bulu babi Tripneustes gratilla yang optimal.

\section{UCAPAN TERIMA KASIH}

Terima kasih kepada Direktur Lembaga Penelitian dan Pengembangan Pendidikan Tinggi Kementerian Pendidikan dan Kebudayaan RI, atas program dalam mengembangkan penelitian kepada dosen, Rektor Universitas Muhammadiyah Luwuk, yang mengizinkan dalam pelaksanaan penelitian, Kepala Laboratorium Nutrisi Ikan IPB, Kepala Laboratorium Kesehatan Ikan IPB, yang membantu analisis proksimat pakan dan analisis histologi gonad bulu babi.

\section{DAFTAR PUSTAKA}

Agatsuma, Sakai Y, Tajima K. 2010. Recent advances in sea urchin aquaculture in Japan. 
Gambar 8. Pembacaan irisan gonad di lima lokasi, periode bulan purnama

\begin{tabular}{|c|c|c|}
\hline Nomor sampel & Gambaran histologi gonad & Hasil pembacaan \\
\hline L1.1 & & $\begin{array}{l}\text { Jenis kelamin: betina } \\
\text { Tahap siklus gametogenesis: tahap IV (end of gametogenesis, } \\
\text { nutitive phagocytosis (NP) exhaustion, dan spawning) }\end{array}$ \\
\hline L4.1 & & $\begin{array}{l}\text { Jenis kelamin: jantan } \\
\text { Tahap siklus gametogenesis : tahap III (gametogenesis dan } \\
\text { nutitive phagocytosis (NP) utilization) }\end{array}$ \\
\hline L4.2 & & $\begin{array}{l}\text { Jenis kelamin: jantan } \\
\text { Tahap siklus gametogenesis : tahap IV (end of gametogenesis, } \\
\text { nutitive phagocytosis (NP) exhaustion, dan spawning) }\end{array}$ \\
\hline $\mathrm{L} 2.1$ & & $\begin{array}{l}\text { Jenis kelamin: betina } \\
\text { Tahap siklus gametogenesis : tahap IV (end of gametogenesis, } \\
\text { nutitive phagocytosis (NP) exhaustion, dan spawning) }\end{array}$ \\
\hline L3.1 & & $\begin{array}{l}\text { Jenis kelamin: jantan } \\
\text { Tahap siklus gametogenesis: tahap III (gametogenesis dan } \\
\text { nutitive phagocytosis (NP) utilization) }\end{array}$ \\
\hline L5.1 & & $\begin{array}{l}\text { Jenis kelamin: betina } \\
\text { Tahap siklus gametogenesis: tahap IV (end of gametogenesis, } \\
\text { nutitive phagocytosis (NP) exhaustion, dan spawning) }\end{array}$ \\
\hline
\end{tabular}

Bull. Aquacul. Assoc. Can. 108: 4-9.

Andrew KNL, Agatsuma Y, Ballesteros E, Bazhin AG, Creaser EP, Barnes DKA, Botsford LW, Bradbury A., Campbell A, Dixon JD, Einarsson S, Gerring P, Bebert K, Hunter M, Hur SB, Johnson CR, Juinio-Menez MA, Kalvass P, Miller RJ, Moreno CA, Palleiro JS, Rivas D, Robinson SML, Schroeter SC, Steneck RS, Vadas RL, Woodby DA, Xiaoqi Z. 2002. Status and management of world sea urchin fisheries. Oceanography and Marine Biology Annual Review 40: 343-425.

Barker MF. 2010. Recent advances in sea urchin aquaculture in New Zealand and Australia. Bull. Aquacul. Assoc. Can. 108: 10-17.
Effendie. 1978. Metode Biologi Perikanan. Bogor: Yayasan Dewi Sri.

[FAO] Food and Agriculture Organitation. 2012. Global aquaculture production (online query) 1959-2009. [terhubung berkala]. http://www. fao.org/ fishery/statistics/global-aquacultureproduction/query/en. [1 Feb 2012].

Hagen NT, Siikavuopio SI. 2010. Recent advances in sea urchin aquaculture in Norway. Bull. Aquacul. Assoc. Can. 108: 18-22.

James P, Siikavuopio S. 2012. A guide to the sea urchin reproductive cycle and staging sea urchin gonad samples. Nofima. Hlm. 1-14.

Jangoux dan Lawrence.1982. Growth model of the reared sea urchin Paracentrotus lividus. 
Faculte des Sciences Laboratoire de Biologie Marine. Hlm. 272.

Keesing JK, Hall KC. 1998. Review of harvests and status of world sea urchin fisheries points to opportunities for aquaculture. J. Shellfish Res. 17: 1.597-1.604.

Kelly MS, Chamberlain J. 2010. Recent advances in sea urchin aquaculture and enhancement in Scotland and Ireland. Bull. Aquacul. Assoc. Can. 108: 23-29.

Lawrence JM, Agatsuma Y. 2007. Ecology of Tripneustes. In: Lawrence JM, editor. Edible Sea Urchin: Biology and Ecology. Ed ke-2. Oxford: Elsevier. Hlm 499-514.

Liu H, Zhu JX, Kelly MS. 2010. Recent advances in sea urchin aquaculture and enhancement in
China. Bull. Aquacul. Assoc. Can. 108: 3037.

Muthiga NA. 2005. Testing for the effects of seasonal and lunar periodicity on the reproduction of the edible sea urchin Tripneustes gratilla (L) in Kenyan coral reef lagoons. Aquaculture 549: 57-64.

Pearce CM, Robinson SMC. 2010. Recent advances in sea urchin aquaculture and enhancement in Canada. Bull. Aquacul. Assoc. Can. 108: 38-48.

Purbiantoro W. 2013. Pengembangan makroalga sebagai stimulan pakan bagi bulu babi dewasa Tripneustes gratilla, Linnaeus [Thesis]. Bogor: Institut Pertanian Bogor. 